\title{
EFFECTS OF FLOWER AGE ON POLLINATION SUCCESS IN LEPANTHES SANGUINEA
}

\author{
Edwin Guevara Ramos, María M. Agosto Pedroza \& Raymond L. Tremblay ${ }^{1}$ \\ University of Puerto Rico - Humacao, Biology Department, Humacao, Puerto Rico, 00791-4300, U.S.A. \\ ${ }^{1}$ Author for correspondence: raymond@hpcf.upr.edu
}

The effect of flower age on pollination has been shown to be important in promoting cross pollination when the sexual expression of flowers is age dependent (Ackerman 1975, Singer \& Koehler 2002). Fruit set in species with protandry or protogyny will frequently be reduced because of the dual sexual characters of the flowers. In protandrous flowers the anthers are mature before the stigma is receptive, and in protogynous plants the stigma is receptive before the anthers mature. In many orchids fruit set is high when hand cross pollinations are performed and this phenomenon could be attributed to a lack of an elaborate mechanism to prevent self pollination (Dressler 1981). Mechanisms for preventing self-pollination could include sequential flowering (Psychilis spp., Ackerman 1989; Malaxis massonii, Aragón \& Ackerman 2001) and dichogamy /protandry (Goodyera oblongifolia, Ackerman 1975; Spiranthes, Catling 1983; Prescottia stachyodes, Singer \& Sazima 2001a; Erythrodes arietina, Singer \& Sazima 2001b; Sauroglossum elatum, Singer 2002; Mesadenella cuspidata, Singer 2002; Notylia nemorosa, Singer \& Koehler 2002).

Lepanthes sanguinea Hook. is an epiphytic and litophytic orchid found in Puerto Rico and Jamaica. It is distributed in the Sierra de Cayey and the Luquillo Mountains, Puerto Rico, and flowers throughout the year (Ackerman 1995). Breeding system and pollinators are unknown as to yet; however, fruit set near Mt. Britton was 5.9\% (Ackerman 1995) suggesting that this plant's reproduction depends on pollinators and is not autogamous. Recent work by Blanco \& Barboza (2001) reports pollination in Lepanthes glicensteinii which was observed to be pollinated by fungus gnats (Bradysia sp., Sciaridae) and possibly through pseudocopulation. We investigated fruit set by cross-pollination of young and old flowers in
Lepanthes sanguinea to determine if this species may be expressing protandrous behaviour.

Thirty orchids were grown in a Wardian case that maintains humidity and temperature at a more or less stable condition. Maximum mean temperature (SE) was $27{ }^{\circ} \mathrm{C} \pm 0.2$ and the minimum mean temperature (SE) was $21^{\circ} \mathrm{C} \pm 0.2$. The maximum mean humidity (SE) was $91 \% \pm 0.1$, and the minimum humidity mean was $77 \% \pm 0.5$. Pollinia were removed with a toothpick from flowers and utilized immediately for pollination or kept within the Wardian case until pollination was performed. Water and plant food were administered frequently to ensure the plant's nutrition. The pollinated flowers age ranged from one to eight days after blossom beginning.

The mean lifespan of un-manipulated flowers and pollinated flowers was not significantly different [mean (s.d.) $=4.6$ (1.6) days; 5.1 (1.5) days, respectively, unpaired t-test $\left.\mathrm{t}_{27,77}=1.648, \mathrm{p}=0.10\right]$. The mean (se) lifespan of fruits was $44.2 \pm 7.1(\mathrm{~N}=6)$ days.

Fruit set was low, only six fruits were produced from 77 pollinations. Flowers of one and two days treatment were not more likely to produce fruits than flowers of more than 3 days (1-2 day old flowers, fruit set 3; no fruits 12; $3+$ day old flowers, fruit set 3 , no fruits 59; Fisher's Exact test, $\mathrm{p}=0.08$ ).

In L. sanguinea hand pollination resulted in a $7.8 \%$ fruit set which compared to data collected by Ackerman (1995) is equal to natural fruit set (5.9\%). We expected a much higher fruit set by hand-pollination as in most orchids fruit set can be elevated by hand cross pollination. In general, naturally pollinated orchids have a mean fruit set of $27.5 \%$ while hand pollinated orchids are much higher $(82.0 \%$; 
Tremblay, Ackerman, Zimmerman \& Calvo, submitted).

Six fruits are not sufficient data points to make a conclusive analysis after five months of intensive pollinations. Furthermore, L. sanguinea plants have not been as productive as other species (L. rupestris, $L$. woodburyana and L. rubripetala; Méndez, Pomales, $\&$ Tremblay, unpublished). The difference in fruit set may be related to resource availability. In a related orchid, L. eltoroensis, flower production is halted while fruits are developing. At least with these preliminary results protandry in this orchid has not been detected.

\section{Literature Cited}

Ackerman, J.D. 1975. Reproductive Biology of Goodyera oblongifolia (Orchidaceae). Madroño 23: 191-198.

Ackerman, J.D. 1989. Limitations to sexual reproduction in Encyclia krugii (Orchidaceae). Syst. Bot. 14: 101109.

Ackerman, J.D. 1995. An orchid flora of Puerto Rico and the Virgin islands. Mem. New York Bot. Gard. 73: 1203.

Aragón, S. \& J.D. Ackerman. 2001. Density effect on the reproductive success and herbivory of Malaxis massonii. Lindleyana 16: 3-12.
Blanco, M. \& G. Barboza. 2001. Polinización en Lepanthes: un nuevo caso de pseudocopulación en las orquídeas.San José, 2do Seminario Mesoamericano de Orquideología y Conservación. Programa de Conferencias: Resúmenes. San José, 23-26 de mayo 2001. p. 13.

Catling, P.M. 1983. Pollination of northeast North American Spiranthes (Orchidaceae). Can. J. Bot. 61: 1080-1093.

Dressler, R.L. 1981. The Orchids: Natural history and classification. Harvard University Press, Cambridge.

Meléndez-Ackerman, E.J., J.D. Ackerman \& J.A. Rodríguez-Robles. 2000. Reproduction in an Orchid can be resource-limited over its lifetime. Biotropica 32: 282-290.

Singer, R.B. 2002. The pollination biology of Sauroglossum elatum Lindl. (Orchidaceae:Spiranthinae): mothpollination and protandry in neotropical Spiranthinae. Bot. J. Linn. Soc. 138: 9-16.

Singer, R.B. \& S. Koehler. 2002. Notes on the pollination biology of Notylia nemorosa (Orchidaceae): do pollinators necessarily promote cross pollination? J. Plant. Res - Abstract.

Singer, R.B. \& M. Sazima. 2001a. The pollination mechanism of three sympatric Prescottia (Orchidaceae: Prescottinae) species in southerneastern Brazil. Ann. Bot. 88: 999-1005.

Singer, R.B. \& M. Sazima. 2001b. Flower morphology and pollination mechanism in three sympatric Goodyerinae orchids from southeastern Brazil. Ann. Bot. 88: 989-997.

Edwin Guevara studies at the University of Puerto Rico at Humacao. He is in the Bachelors Program in Biology with a concentration in wildlife management. He was born in Pennsylvania and currently lives in Puerto Rico. This is his fourth year at Humacao and the investigation on Lepanthes sanguinea that he has done with Dr. R.L. Tremblay has been his first research experience. As for his aspirations as a scientist and biologist, he hopes to get a master's degree in either vertebrate biology or environmental science. 